\title{
Lietetuotteiden käyttö ohran lannoitukseen
}

Petri Kapuinen

MTT, Kasvintuotannon tutkimus, Maaperä ja kasvinravitsemus, 21500 Piikkiö, petri.kapuinen@mtt.fi

\section{Tiivistelmä}

Lietetuotteiden kestävät käyttömäärät pinta-alayksikköä kohti edellyttävät niiden käyttöä viherrakentamisen lisäksi maanviljelyksessä. Vaikka lietetuotteet luetaankin maanparannusaineisiin, niillä on yleensä merkittävä lannoitusvaikutus. Lietetuotteiden käyttöä maanviljelyssä säätelee lannoitevalmistelainsäädännön lisäksi valtioneuvoston päätös puhdistamolietteen käytöstä maanviljelyksessä, ns. nitraattiasetus sekä ympäristötukijärjestelmä. Nämä yhdessä rajoittavat typen ja fosforin sekä haitallisten metallien levitysmäärärajoitusten kautta käyttömäärät niin pieniksi, että maanparannusvaikutus jää käytännössä vähäiseksi. Tyypillisesti käyttömäärät voivat olla alle 50 t/ha 4 - 5 vuoden kuluessa. Lietetuotteet ovat erityisesti fosforin, jota on pelloissa ympäristökuormituksen kannalta usein jo liikaakin, lähteitä. Niiden liukoisen typen märä on tyypillisesti pieni, ja orgaanisen typen käyttö kasvinravinteena puolestaan on vaikeasti hallittavissa.

Suurin osa lietetuotteista on mädätetty ja/tai kompostoitu aumassa. Niiden typpilannoitusvaikutusten selvittämiseksi tutkittiin kalkkistabiloidun, kompostoidun ja Kemicond-käsitellyn lietteen ominaisuuksia ohralla 2-vuotisessa kenttäkokeessa. Käyttömäärät pyrittiin maksimoimaan sitä rajoittavien tekijöiden puitteissa, jolloin levitys saattoi useimmiten toistua vain 4 - 5 vuoden välein. Liukoisen typen määrä laskettiin ns. lanta-analyysin mukaisesti ja kokonaisfosforista otettiin huomioon $40 \%$. Liukoisen typen määrä pyrittiin tasaamaan tavoitetasoon väkilannoitteella. Lietetuote mullattiin tunti levityksestä ja kylvettiin välittömästi, mullattiin kylvön yhteydessä kylvölannoittimen vantailla, levitettiin kylvön jälkeen katteeksi tai vasta kasvustoon 1 - 2 -lehtivaiheessa.

Kalkkistabiloitu liete kattoi 8,9 - 16,5\% ohran liukoisen typen annoksesta. Vuonna 2006 sato ei eronnut merkitsevästi väkilannoitteella saatavasta, mutta lietteen multaaminen ennen kylvöä tai kylvämällä tuotti merkitsevästi paremman satotulokseen kuin kattaminen kylvön jälkeen. Vuonna 2007 sato pieneni merkitsevästi 15,3 \% riippumatta levitysmenetelmästä. Ratkaisevaa näyttäisi olevan multauksen onnistuminen hankalasti mullattavalla materiaalilla, jota kalkkistabiloitu liete usein on.

Kompostoitu liete kattoi 0,3-8,2 \% liukoisen typen annoksesta. Sen käyttö ei vaikuttanut satoon merkitsevästi vuonna 2006 mutta vuonna 2007 sato aleni merkitsevästi keskimäärin 9,5 \%, kun liete mullattiin saman tien kylvämällä, levitettiin katteeksi tai vasta kasvustoon. Kompostoidusta lietteestä ei näyttäisi olevan oleellista haittaa sadon muodostukselle hyvin mullattuna ennen kylvöä.

Muista lietetuotteista poiketen Kemicond-käsitellystä lietteestä saatiin koko liukoisen typen annos, jolloin tuotteella oli hyvin suuri potentiaalinen vaikutus satoon. Vuoden 2006 sato oli yhtä suuri kuin väkilannoitteella saatu levitysmenetelmästä riippumatta, mutta vuonna 2007 sato oli merkitsevästi 38,4 \% pienempi, jos liete mullattiin kylvämällä. Muut menetelmät tuottivat lähes yhtä suuren satotappion, mutta ilman tilastollista merkitsevyyttä.

Kemicond-käsiteltyä lietettä lukuun ottamatta satovaikutukset olivat pääasiassa muita kuin typpivaikutuksia, koska pääosa typestä jouduttiin antamaan joka tapauksessa väkilannoitteena. Tuloksia on vaikea yleistää kaikkiin periaatteessa tutkittuihin ryhmiin kuuluviin tuotteisiin, koska ominaisuudet niiden sisällä vaihtelevat runsaasti. Runsaasti liukoista typpeä mukanaan tuovien tuotteiden satovaikutukset voivat olla arvaamattomia, ja sadon kannalta oleellista on hyvä kylvötulos.

Asiasanat: puhdistamoliete, lietetuotteet, mädätys, kompostointi, kalkkistabilointi, Kemicond-käsittely, levitysmenetelmä, kasvustoon levitys, multaus, ohra, mallasohra, rehuohra, lannoitusvaikutus, maanparannusvaikutus, typpi, fosfori, haitalliset metallit 


\section{Johdanto}

Jotta lietetuotteiden käyttö olisi kestävällä pohjalla, niitä on käytettävä viherrakentamisen lisäksi maanviljelyksessä. Maatalous on ainoa merkittävä ravinteiden luonnollinen käyttökohde, mutta lietetuotteiden maanviljelyskäyttö on vähentynyt merkittävästi koko Suomen EU-jäsenyyden ajan sen käyttöön liittyvien määräysten kiristyessä (VN 1994, 2000, Eduskunta 2006, MMM 2007a). Vuosina 2004 ja 2005 maanviljelyskäytön osuus putosi jyrkästi jonkin aikaa vallinneelta noin $15 \%$ :n tasolta tasolle noin 3 \% ilmeisesti liittyen lannoitevalmistelainsäädännön valmistelutyön aikana vallinneeseen epätietoisuuteen tulevista uusista vaatimuksista. Nykyisin suurin osa lietteestä on mädätetty ja/tai kompostoitu aumassa ja käytetään viherrakentamisessa tai kaatopaikkojen katteena. Lannoitevalmistelainsäädäntö (Eduskunta 2006, MMM 2007a) on kiristänyt lietetuotteiden viherrakennuskäyttöä koskevia määräyksiä suhteessa maanviljelyskäyttöön ja mahdollisuudet sijoittaa liete kaatopaikkojen katteeksi vähenee niiden kattamisen edistyessä (VN 2006). Tulevaisuudessa paine lietetuotteiden maatalouskäytön lisäämiseen kasvaa merkittävästi.

Uuden lannoitevalmistelainsäädännön (Eduskunta 2006, MMM 2007a) voimaantulon jälkeen lietetuotteita on käytännössä voinut käyttää ainoastaan lannoitevalmisteina. Teoriassa käsittely pelkästään valtioneuvoston päätöksen puhdistamolietteen käytöstä maanviljelyksessä (Lietepäätös) (VN 1994) mukaisesti on mahdollista, kun tila tai tilaryhmä käsittelee lietteen itse ja käyttää sen hallinnassaan olevilla pelloilla. Lannoitevalmisteina kaikki lietetuotteet luetaan maanparannusaineisiin, koska lannoitteissa ei sallita puhdistamolietettä. Maaviljelyksessä lietetuotteiden lannoitusvaikutus on kuitenkin huomattava suhteessa niiden maanparannusvaikutukseen ympäristölainsäädännön (VN 1994, 2000) ja ympäristötukijärjestelmän (MMM 2007b) eri järjestelmien perusteella sallittujen määrien puitteissa. Lietetuotteet ovat ennen kaikkea fosforilannoitteita, mutta joillakin niistä on merkittävä typpilannoitusvaikutus, ja niiden mukana saadaan merkittävä määrä myös muita kivennäisravinteita. Ne sopivat erityisesti sellaisille maille, joiden fosforiluku on pieni. Käyttömäärää rajoittaa lähinnä lannoitevalmistelainsäädäntö (kadmium) (MMM 2007a), maatalouden ympäristötukijärjestelmä (fosfori ja liukoinen typpi) (MMM 2007b) ja Lietepäätös (haitalliset metallit) (VN 1994). Tyypilliset käyttömäärät ovat alle 50 t/ha 4 - 5 vuoden kuluessa.

Suomessa viljelysmaan P-luvut ovat yleensä liiankin korkeat, mikä vähentää kiinnostusta lietetuotteiden käyttöön. Lietetuotteen fosforilla ei ole viljelijälle arvoa, jos hänen peltonsa ei tarvitse sitä, vaikka sen käyttömahdollisuuksia jonkin verran olisikin. Tällöin lietetuotteen arvo perustuu vain sen sisältämän liukoisen typen arvoon, joka yleensä on pieni. Erilaisten lietetuotteiden typpilannoitusvaikutuksesta peltoviljelyssä on hyvin vähän tietoa, ja yleensä sen hallinta ja ennustaminen on vaikeaa. Typpilannoitusvaikutuksen hallinnan vaikeus voi johtaa merkittäviin sadon määrän ja laadun alennuksiin riippumatta poikkeaman suunnasta. Epämääräisen typpilannoitusvaikutuksen haittoja voidaan vähentää levittämällä lietettä useammin, mutta vastaavasti vähemmän kerralla, mutta toisaalta se on omiaan lisäämään levityskustannuksia lietetonnia kohti. Kalkkistabiloidun lietteen kalkitusvaikutuksen arvo voi olla suurempi kuin lannoitusvaikutuksen. Lietetuotteiden levitys on yleensä aina erillinen viljelytoimenpide omine kustannuksineen.

Lietetuotteet kuuluvat lannoitevalmisteasetuksen tyyppinimiryhmiin orgaaniset maanparannusaineet tai sellaisenaan maanparannusaineena käytettävät sivutuotteet (MMM 2007b). Jälkimmäisen typpinimiryhmän tyyppinimien mukaisiin ryhmiin kuuluviin lietetuotteisiin sovelletaan myös Lietepäätöstä (VN 1994). Käytännössä tämä merkitsee sitä, että levitysalueen haitallisten metallien pitoisuudet ja happamuus on analysoitava ennen levitystä ja että kadmiumin kuormituksen lisäksi seurataan myös muiden haitallisten metallien kuormitusta. Haitallisten metallien pitoisuudet maassa eivät yleensä ole esteenä lietetuotteiden käytölle mutta liiallinen happamuus voi olla. Kaikkien tämän ryhmän lietetuotteiden käyttö aiheuttaa viiden vuoden viljelyrajoituksen sellaisten kasvien viljelyyn, joista syödään maanalainen osa tai maanpäällinenkin osa käytetään yleensä tuoreena (EEC 1986, VN 1994). Orgaanisten maanparannusaineiden ryhmään kuuluvien lietetuotteiden käyttö ei lähtökohtaisesti näitä rajoituksia aiheuta, mutta tyyppinimikohtaisesti viljelyrajoitukset saattavat olla yhtä laajat kuin jälkimäisessä ryhmässä ja varoaika 2 vuotta (MMM 2007a). Toisaalta korkeimman statuksen omaava tyyppinimi, maanparannuskomposti, ei aiheuta mitään viljelyrajoituksia edes käyttövuonna.

Lannoitevalmistelainsäädännön (Eduskunta 2006, MMM 2007a) lisäksi on aina noudatettava ympäristölainsäädäntöä esimerkiksi ns. nitraattiasetusta (VN 2000) ja käytännössä aina myös ympäristötukijärjestelmän ehtoja (MMM 2007b). Lietepäätöksen (VN 1994) noudattamista valvotaan täydentävien ehtojen eli tilatuen ehtojen noudattamisen valvonnan yhteydessä, kun on käytetty lietetuotteita, joita se koskee (VN 2007). Tämän tutkimuksen koekasvin ohran viljelyyn lietetuotteiden käyttö ei aiheuta rajoituksia. 
Lannoitevalmistelainsäädäntö (Eduskunta 2006, MMM 2007a) annettiin tutkimuksen kuluessa eikä sitä voitu varsinaisesti ottaa huomioon tutkimuksessa esimerkiksi siten, että käytetyt lietetuotteet olisivat olleet täysin tyyppinimiluettelon mukaisia.

Tutkimuksessa oli mukana kalkkistabiloitu, kompostoitu ja Kemicond-käsitelty liete. Kalkkistabiloitu liete on sellaisenaan maanparannusaineena käytettävä sivutuote ja sen typpilannoitusvaikutus on lietetuotteiden keskitasoa ja tyypillisesti hidas. Kompostoitu liete oli pitkään vanhennettua ja sen typpilannoitusvaikutus on käytännössä olematon. Käytetty jälkikompostoitu Kemicond-käsitelty liete oli lähinnä orgaanisiin maanparannusaineisiin kuuluvan tyyppinimen hapotettu ja stabiloitu puhdistamoliete erotukseksi toisesta Kemicond-käsiteltyä lietettä tarkoittavasta typpinimestä kemiallisesti hapetettu puhdistamoliete, joka kuuluu sellaisenaan maanparannusaineena käytettäviin sivutuotteisiin. Kemicond-käsitelty liete kompostoituu, kun sen kuiva-ainepitoisuus on kuivauksen jälkeen vähintään noin 30 \% tai se nostetaan siihen tukiaineella. Kompostoitumisen aikana, joka kestää noin kaksi viikkoa, lämpötila nousee nopeasti ja kompostiin muodostuu merkittävä määrä liukoista typpeä. Sen määrä on niin merkittävä, että ohran tarvitsema liukoinen typpi voidaan periaatteessa ottaa kokonaan lietteestä ja jopa joka vuosi riippuen lietteen alkuperästä. Varoaika on esimerkiksi jälkikompostoimalla stabiloituna 2 vuotta, muuten 5 vuotta.

Tutkimuksen tavoitteena oli selvittää lietetuotteiden käytön vaikutus satoon sallituilla käyttömäärillä ja niiden käytön taloudellinen mielekkyys.

\section{Aineisto ja menetelmät}

Koekenttä perustettiin vuonna 2006 Ypäjälle (P6048,0', I23 ¹9,6') hiesusavelle ja 2007 Jokioisiin (P6051,0’, I23 ²7,5’) aitosavelle. Ypäjällä maan pH oli 5,81, Ca-luku 1147 mg/l, K-luku 101 mg/l, Mgluku 179 mg/l, P-luku 7 mg/l, org. C-pit. oli 2,51 \% ja humuspit. 4,35 \%. Maan pH oli ohralle sopivan alueen alarajalla, P-,K- ja Mg-luku olivat välttävät, Ca-luku oli huononlainen ja humuspitoisuus multavaksi luokiteltavan alueen keskivaiheilla. Kokeen lietetuotteista ainoa sellaisenaan maanparannusaineena käytettävä lietetuote oli kalkkistabiloitu liete, jota käytettäessä maan pH:n pitää olla yli 5,5 (VM 1994). Se ei siten olisi saanut olla merkittävästi alempi. Koealue oli analyysitietojen perusteella hyvin potentiaalista lietetuotteiden käyttöaluetta. Jokioisissa maan pH oli 6,27, Ca-luku 2705 mg/l, K-luku 331 mg/l, Mg-luku 578 mg/l, P-luku 7,5 mg/l, org. C-pit. 3,66 \% ja humuspit. 6,33 \%. pH oli ohralle sopivan alueen keskivaiheille. Koealue oli multavampi kuin Ypäjällä kuuluen runsasmultaiseen luokkaan. Vuoden 2006 ei ollut aivan yhtä hyvää levitysaluetta kuin vuonna 2006, koska se oli runsasmultaista ja tyydyttävässä luokassa ollutta fosforia lukuun ottamatta kivennäisravinteiden pitoisuudet olivat hyvässä luokassa.

Kokeessa tutkittiin kalkkistabiloidun, kompostoidun ja Kemicond-käsitellyn lietteen käyttöä ohralla eri levitysmenetelmillä kylvönyhteydessä tai kasvustoon levitettynä. Koemuoto osaruutukoe neljällä kerranteella. Koeruutujen leveys oli $3 \mathrm{~m}$ ja pituus $20 \mathrm{~m}$. Koekasvina oli Annabell-ohra (siemenmäärä 500 $\mathrm{kpl} / \mathrm{m}^{2}$ ). Ohra kylvettiin ja koejäsenen mukainen täydennyslannoite mineraalilannoitteena sijoitettiin kylvölannoittimella. Lietekoejäsenissä N-lannoituksen tavoitetasona oli $100 \mathrm{~kg} /$ ha liukoista typpeä lantaanalyysimenetelmällä määritettynä. Lietteet levitettiin kylvön yhteydessä 1.6.2006 ja 21-22.5.2007. Kasvustoon levitettiin vain kompostoitua puhdistamolietettä 19.6.2006 ja kalkkistabiloitua ja kompostoitua lietettä 7.6.2007. Lietekoejäsenten lisäksi kenttäkokeessa oli koejäsenet sianlietelannan ja elintarviketeollisuuden sivuvirran seoksesta hygienisoituna, kompostoituna ja sen jälkeen vielä separoituna rejektiksi ja kiintojakeeksi eri levitysmenetelmillä. Näiden koejäsenten osalta tulokset on vuoden 2006 raportoitu muualla (Kapuinen ym 2008) ja 2007 osalta julkaisematta. Kokeisiin liittyi erilliset typpitasot: 0, 50, 75, 100, 125 ja 150 kg/ha mineraalilannoitteella (GrowHow Kevätviljan Y6; 17-4-13) tuotantofunktion selvittämiseksi. Koeasetelmassa tutkittiin lietetuotteiden typpilannoitusvaikutusta ja mahdollisia muita kuin kasvinravitsemukseen perustuvia vaikutuksia. Lietetuotteiden fosforin määrällä tai käyttökelpoisuudella ei ollut vaikutuksia satotuloksiin. Lietetuotteita pyrittiin käyttämään vastaten $100 \mathrm{~kg} / \mathrm{ha}$ liukoista typpeä lantaanalyysimenetelmällä määritettynä sisältäen kuitenkin mahdollisen nitraattitypen, jos kasveille käyttökelpoisen fosforin määrä neljälle (2006) tai viidelle (2007) tai haitallisten metallien määrä neljälle vuodelle ei rajoittanut määrää pienemmäksi. Tällöin levitysmäärä määräytyi rajoittavimman tiedossa olleen pitoisuuden perusteella ja liukoisen typen määrä pyrittiin tasamaan mahdollisimman lähelle tavoitetasoa mineraalilannoitteen typellä.

Kalkkistabiloitu liete Kaarinan puhdistamolta oli kumpaisenakin vuonna kalkkistabiloitu sen ilmoituksen mukaan käyttäen 30 kg/t poltettua kalkkia (CaO). Stabilointia jatkettiin käyttämällä CaO 150 kg/t lietettä, jotta saavutettiin $55^{\circ} \mathrm{C}$ :een lämpötila kahdeksi tunniksi. Vuonna 2007 lietteen pH oli käsittelyn 
jälkeen 13,9. Lietteen koostumus oli: 5,3 kg kok. N/t, 0,3 liuk. N kg/t ja 1,36 kg /t kasveille käyttökelpoista fosforia (käyt. P), ka 41,6 \%. Sitä levitettiin 49,4 t/ha vastaten 14,8 kg liuk. N/ha, 60 kg käyt. P/ha. Täydennyslannoituksessa annettiin $75 \mathrm{~kg}$ liuk. N/ha ja 11,3 kg P/ha. Levitysmäärä määräytyi silloisen ympäristötuen neljän vuoden tasausjakson mukaisesti, 4 v. x 15 kg/ha => 60 kg/ha. Haitallisista metalleista Cd oli rajoittavin, ja sitä kertyi 5,6 g/ha neljän vuoden jakson sallitun määrän ollessa 6,0 g/ha.

Vuonna 2007 lietteen saapuessa noin 1,5 tunnin kuluttua käsittelystä Jokioisille sen pH 12,76 ja kapit. 33,1 \% (30 kg/t CaO). Lietteen koostumus oli 6,8 kg kok. N/t, 0,2 kg liuk. N/t ja 1,2 kg käyt. P/t ja 0,5 kg kok.-K/t. Levitysmäärä, 68,1 t/ha, valittiin ennakkonäytteen P-pitoisuuden (2,6 kg/t) perusteella siten, että käyttöstrategiana oli antaa kerralla viiden vuoden P-annos $70 \mathrm{~kg} / \mathrm{ha} \mathrm{(14} \mathrm{kg/ha} \mathrm{v).} \mathrm{Levityksen}$ yhteydessä otettujen näytteiden P-pitoisuuden poiketessa ennakkonäytteen vastaavasta muun muassa välivarastoinnissa tapahtuneen kuivumisen (ka 33,1 \% => 37,8 \%) takia annokseksi muodostui 83,5 kg käyt. $\mathrm{P} / \mathrm{ha}$. Lietteestä tuli vain $16 \mathrm{~kg}$ liuk. N/ha, joten suurin osa siitä jouduttiin antamaan mineraalilannoitteena. Kadmiumia tuli 3,8 g/ha sallitusta 4 vuoden annoksesta 6 g/ha. Levitettäessäkin lietteen $\mathrm{pH}$ oli 12,9, joten sen voitiin olettaa olevan hygienista. $30 \mathrm{~kg} \mathrm{CaO} / \mathrm{t}$ lietettä käytettiin vain yhdessä koejäsenessä. Muissa koejäsenissä käytettiin 30+150 kg CaO/t lietettä. Lietteen emäksisyys ei noussut lisäkalkkistabiloinnissa vaan pH:ksi jäi tasoon 13,0. Lisäkalkki kuivatti lietettä 52,8 \%:iin parantaen sen levitysominaisuuksia merkittävästi. 2/3 kuivumisesta selittyy kalkin kuiva-ainelisästä, loppu veden haihtumisesta. Samalla nitraattitypen määrä suhteessa ammoniumtypen määrään väheni puoleen. Lietteen koostumus oli 5,5 kg kok. N/t, 0,2 liuk. N/ha ja 1,0 kg käyt. P/t. Levitysmäärä 58,5 t/ha vastasi 9,8 kg liuk. N/ha lietteestä ja 59,3 kg käyt. P/ha. Tällöinkin kadmiumin ollessa rajoittavin haitallinen metalli sitä tuli 4,6 g/ha sallitusta 4 vuoden annoksesta 6,0 g/ha.

Kokeessa käytetty kompostoitu liete oli Uudestakaupungista. Sitä oli vanhennettu kompostointikentällä useita vuosia ja se oli hyvin kuivaa vastaten stabilisuudestaan riippuen jotakin orgaanisten maanparannusaineiden typpinimistä. Siinä oli vielä vähemmän liukoista typpeä kuin kalkkistabiloidussa lietteessä mutta suurimmalta osin nitraattimuodossa, joten todennäköisesti se olisi voinut olla maanparannuskompostia, jolloin sillä ei olisi mitään erityisiä käyttörajoituksia tai karanteeniaikaa. Lietteen koostumus oli vuonna 2006 7,4 kg kok. N/t, 0,02 kg liuk. N, 3,2 kg käyt. P/t ja ka-pitoisuus 46,4 \%. Alhainen liukoisen typen pitoisuus johtuu luvusta puuttuvasta nitraattitypestä, jonka pitoisuus lieni sama, $0,2 \mathrm{~kg} / \mathrm{t}$ kuin vuonna 2007. Sen pH oli keväällä 8,0 ja kesällä 8,6, joten se oli varsin emäksistä. Vuonna 2006 sitä käytettiin 17,3 t/ha kylvön yhteydessä tai kasvustoon levittäen. Sen mukana tuli vain 300 g liuk. N/ha mutta 55,6 kg käyt. P/ha. Rajoittavin haitallinen metalli oli Cd, jonka määrä 5,7 g/ha neljän vuoden sallitusta annoksesta 6,0 g/ha. Käytännössä koko liukoinen typpi 100 kg/ha tuli mineraalilannoitteen mukana. Vuonna 2007 lietteen koostumus oli 6,5 kg kok. N/t, 0,2 kg liuk. N/t, 3,1 kg käyt. P/t ja ka-pitoisuus 46,2 \%. Tuotetta käytettiin 54,2 t/ha, mutta se johti suureen hyvin168,8 kg käyt. P/ha ja kadmium 23,3 g/ha annokseen. haitallisista metalleista Cd oli rajoittavin. Tavoitetta $70 \mathrm{~kg} / \mathrm{ha}$ vastaava levitysmäärä olisi ollut vain $24,7 \mathrm{t} / \mathrm{ha}$. Sen $\mathrm{pH}$ oli 5,6, joten se oli vuodesta 2006 poiketen hyvin hapanta. Logistisesti tuote on edullisempi fosforin lähde kuin kalkkistabiloitu liete, koska sopiva käyttömäärä on sen kuivuuden takia vain noin $40 \%$.

Vuonna 2006 lyhyen aikaa jälkikompostoidussa Kemicond-käsitellyssä lietteessä oli 11,9 kg kok. N/t, 3,4 kg liuk. N/t, 2,8 kg käyt. P/t ja kuiva-ainetta 38,4 \%. 11 kk jälkikompostoidussa Kemicondkäsitellyssä lietteessä oli 24,2 kg kok. N/t, 9,5 kg liuk. N/t ja kuiva-ainetta 58,6 \%. Lyhyen aikaa jälkikompostoitua Kemicond-käsiteltyä lietettä käytettiin 28,6 t/ha vastaten 98,1 kg liuk. N/ha ja 80,6 kg kasv. $\mathrm{P} / \mathrm{ha}$. Sen mukana tuli kadmiumia 4,1 g/ha sallitusta annoksesta 6,0 kg/ha. Pitkään kompostoitua Kemicond-käsiteltyä lietettä käytettiin vain 9,6 t/ha vastaten 90,8 kg liuk. N/ha. Vuonna 2007 saatu stabiloimaton Kemicond-käsitelty liete oli hyvin märkää, ja siihen jouduttiin lisäämään $2 \mathrm{~m}^{3}$ turvetta lietekuutiometriä kohti ennen kuin se saatiin kompostoitumaan. Vuonna 2007 ainoastaan käytetty lyhyen aikaa jälkikompostoitu Kemicond-käsitelty liete sisälsi 7,3 kg kok. N/t, 3,3 kg liuk. N/t ja 0,5 kg kasv. P./t ja 26,4 \% kuiva-ainetta. Erityisesti suuren P-pitoisuuseron vuosien välillä selittää se, että Kemicond-käsitellyn lietteen raaka-aine tuli vuosittain eri puhdistamoista, mutta muiden lietteiden keskenään samoista puhdistamoista molempina vuosina. Vuonna 2007 käytetty 27,5 t/ha Kemicond-käsiteltyä lietettä sisälsi 91,1 kg liuk. N/ha ja vain 13,6 kg käyt. P/ha. Kadmiumin kuormitus 2,1 g/ha olisi kuitenkin rajannut levityksen joka toiseen vuoteen, jolloin kertalevitysmäärä olisi voinut olla käytettyä hieman suurempi.

Lietteiden levitykseen käytetyt menetelmät olivat:

1) lietteen pintalevitys, jota seurasi välitön multaus kylvölannoittimella samalla kylväen,

2) juuri kylvölannoittimella katetun kylvöksen kattaminen lietteellä,

3) lietteen pintalevitys, multaus tunnin kuluttua s-piikkiäkeellä ja kylvö kylvölannoittimella sekä 
4) levitys kasvustoon.

Kaikki täydennyslannoitukset annettiin kylvölannoittimen sijoitusvantaiden kautta kylvön yhteydessä samalla ajokerralla kylvön kanssa. Edellisten lisäksi oli vuonna 2006 erityiskäsittely 11 kuukautta kompostoidulla Kemicond-käsitellyllä lietteellä ja vuonna 200730 kg CaO/t kalkkistabiloidulla lietteellä levitystavalla levitystavalla 3.

Tässä yhteydessä raportoidaan sadon määrä 15 \%:n kosteudessa ja 100 kg N/ha lannoitustasossa. Puuttuva pylväs kuviossa 1 merkitsee, että käsittely ei ollut mielekäs tai materiaalia ei ollut riittävästi.

\section{Tulokset ja tulosten tarkastelu}

Kalkkistabiloidulla lietteellä saadut normisadot eivät vuonna 2006 poikenneet merkitsevästi mineraalilannoitteella saadusta sadosta (kuvio 1). Eri levitysmenetelmien välillä oli kuitenkin merkitseviä eroja. Paras normisato saavutettiin multaamalla kalkkistabiloitu liete välittömästi levityksen jälkeen kylvölannoittimella kylvön yhteydessä tai multaamalla se vasta tunnin kuluttua levityksestä joustopiikkiäkeellä ja kylvämällä ohra erikseen kylvölannoittimella. Sen sijaan kattaminen eli lietteen levittäminen kylvön jälkeen pellon pinnalle tuotti merkitsevästi 11,3 \% edellä mainittuja vaihtoehtoja pienemmän normisadon. Kalkkistabiloidun lietteen liukoisen mukana tulleen liukoisen typen osuus koko liukoisen typen määrästä oli pieni (16,5 \%), jolloin sadonmuodostus perustui pääosin mineraalilannoitteen typpeen. Kuitenkin multauksen jäänti kokonaan pois ilmeisesti johti siihen, että lähes koko lietteen liukoinen typpi menetettiin ammoniakkina ilmaan, ja sato aleni vastaavasti verrattuna käsittelyihin, joissa liete mullattiin. Vuonna 2006 kalkkistabiloitua lietettä ei riittänyt kasvustoon levitykseen.

Vuonna 2007 kalkkistabiloidun lietteen käyttö alensi merkitsevästi keskimäärin 15,3 \% ohran normisatoa, vaikka liukoisesta typestä vain pieni osa, 8,9 \% tuli lietteestä (kuvio 1). Eri levitysmenetelmien ja -aikojen tai kalkkimäärien välillä ei ollut merkitsevää ero, vaikka kylvön aikaan pintaan levitetty tunnin kuluttua mullattu liete riippumatta kalkin määrästä ja levitys vasta kasvustoon tuottivat suurimmat mitatut satotappiot. Multaus varpajyrä-äkeellä ei ollut ilmeisesti riittävä, vaan johti huonoon kylvötulokseen, ja kasvustoon levitys ilmeisesti vaurioitti kasvustoa. Suurempikaan kalkkimäärä ei riittänyt kuivattamaan lietettä niin, että se ei olisi huonontanut kylvötulosta. Kylvötuloksen huonontumisen ja kasvuston vaurioitumisen merkitys korostui vuonna 2007, koska suurin sato saavutettiin jo N-tasolla $50 \mathrm{~kg} / \mathrm{ha}$, jolloin lisätypestä oli lähinnä vain vahinkoa. Niin ikään lietteen levitys kasvustoon, joka oli jo kylvön yhteydessä sijoitettuna saanut $82 \mathrm{~kg} /$ ha mineraalilannoitteen typpeä, ei ollut jälkikäteen tarkastellen näissä olosuhteissa mielekästä.

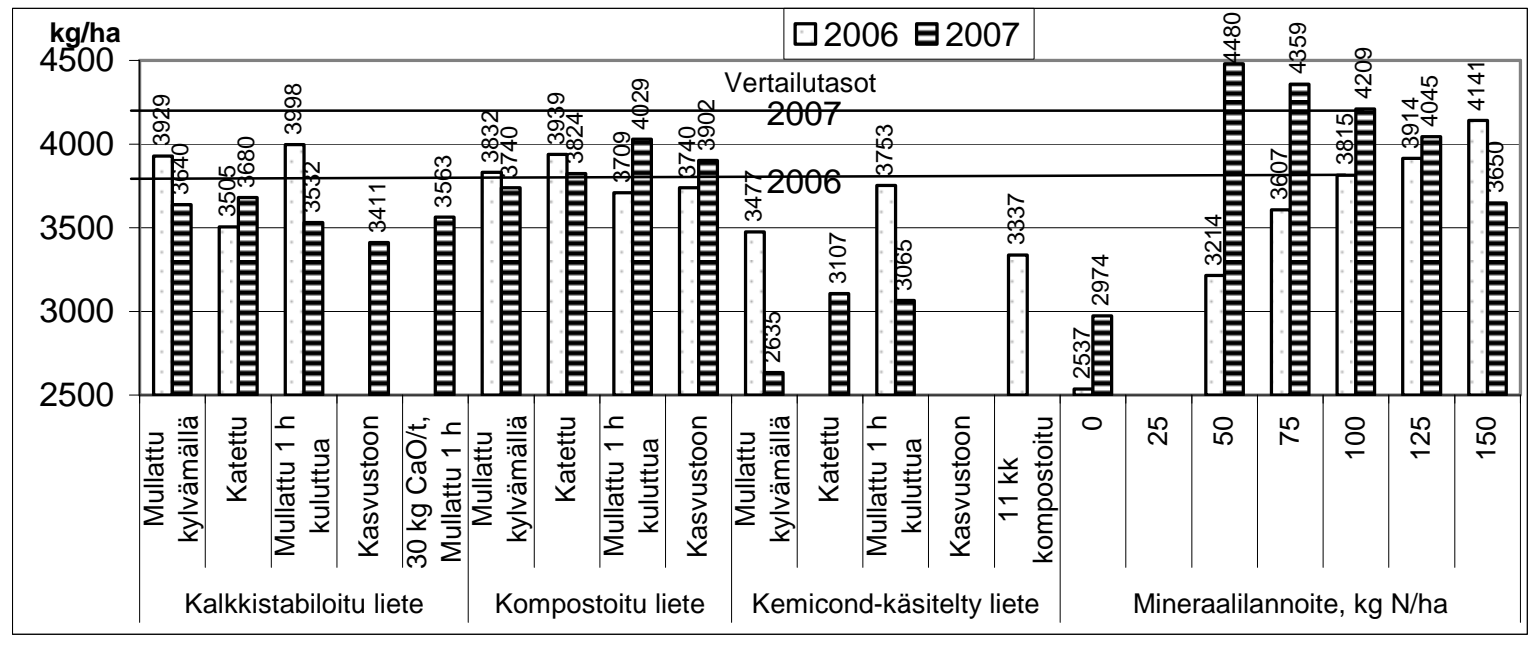

Kuvio 1. Typpitasokorjatut (100 kg N/ha) normisadot (kosteus $15 \%$ ) eri lietekäsittelyillä verrattuna mineraalilannoitteella saavutettaviin

Myöskään kompostoidulla lietteellä vuonna 2006 saatu normisato ei merkitsevästi eronnut mineraalilannoitteella saadusta. Tämä on luonnollista, koska käytännössä lähes koko liukoisen typen annos tuli mineraalilannoitteesta. Lietteestä tuli 0,3-8,2 \% liukoisesta typestä. Myöskään levitysmenetelmien välillä ei ollut merkitsevää eroa. Kompostoitu liete oli fysikaalisilta ominaisuuksiltaan sellaista, että se ei huonontanut kylvötulosta eikä sen kasvustoon levittämisestäkään ollut haittaa. Sen sijaan vuonna 2007 sato 
aleni merkitsevästi keskimäärin 9,5 \% verrattuna mineraalilannoitteen käyttöön, kun liete mullattiin kylvölannoituksella tai kylvös katettiin, taikka liete levitettiin vasta kasvustoon. Eri levitysmenetelmien tai aikojen välillä ei ollut kuitenkaan keskenään merkitsevää eroa. Vuonna 2007 käytetyn määrän aiheuttama Cd-kuorma oli selvästi liian suuri. Levitysmäärä oli myös fosforimäärän suhteen selvästi liian suuri. Kadmiumin puolesta levitysmäärä olisi voinut olla vain 4,5 t/ha vuodessa ja kerta-annos 14 t/ha. Tämä olisi johtanut myös fosforimäärän suhteen varsin sopivaan tasoon keskimäärin 11,3 kg/ha kasveille käyttökelpoista fosforia vuodessa. Käyttömäärän ollessa näin pieni mahdolliset negatiiviset satovaikutukset myös pienenevät tai poistuvat.

Myöskään Kemicond-käsiteltyä lietettä vuonna 2006 saaneiden käsittelyiden sadot eivät poikenneet merkittävästi mineraalilannoitteella saadusta, vaikka saadut mitatut sadot olivat 11,7 \% pienemmät. Koska lietettä ei ollut riittävästi käytettävissä, lyhyen aikaa kompostoitua lietettä käytettiin vain multaamalla se tunnin kuluttua levityksen jälkeen kylvölannoittimella kylvämällä tai multaamalla se tunnin kuluttua levityksestä joustopiikkiäkeellä, ja kylvämällä se välittömästi tämän jälkeen kylvölannoittimella. Lisäksi käytettiin jälkimäisellä tavalla 11 kuukautta kompostoitua Kemicond-käsiteltyä lietettä. Näiden kolmen käsittelyn välillä ei ollut merkitsevää ero normisadossa. Vuonna 2007 lietteen multaaminen kylvön yhteydessä kylvämällä välittömästi levityksen jälkeen, alensi normisatoa merkitsevästi 38,4 \% mineraalilannoitteen käyttöön nähden. Muiden levitysmenetelmien käyttö johti lähes yhtä suureen sadonalennukseen, mutta suuren hajonnan ja vain kolmen toiston takia erot eivät muodostuneet merkitseviksi. Eri levitysmenetelmien välillä ei ollut merkitsevää eroa. Vuoden 2007 Kemicond-käsitellyn lietteen kompostoimiseksi jouduttiin käyttämään poikkeuksellisen suuri määrä turvetta tukiaineena sen märkyyden takia, mikä saattoi merkittävästi vaikuttaa tuotteen ominaisuuksiin. Olosuhteet olivat muutoinkin poikkeukselliset, koska suurin satotaso saavutettiin jo N-tasolla $50 \mathrm{~kg} / \mathrm{ha}$. Kemicond-käsitellyn lietteen N-lannoitusvaikutus saattoi olla takapainotteinen ja oli suuri suhteessa muiden lietetuotteiden vastaavaan, mikä kokeen olosuhteissa asetti sen huonompaan asemaan suhteessa muihin lietetuotteisiin, joiden käsittelyissä typpi tuli pääosin nopeavaikutteisesta mineraalilannoitteesta.

Vuonna 2006 lietetuotteiden käyttö ei yleisesti ottaen alentanut ohrasatoa verrattuna pelkän mineraalilannoitteen käyttöön, koska lisätypestä oli hyötyä sadonmuodostuksessa. Kemicond-käsiteltyä lietettä lukuun ottamatta lietetuotteilla oli hyvin pieni kontribuutio ohran N-lannoituksessa. Mahdolliset satovaikutukset riippuivat lähinnä levityksen yleensä negatiivisista mekaanisista vaikutuksista. Niinpä kalkkistabiloidun lietteen levittäminen vasta kylvön jälkeen katteeksi alensi satoa jonkinmoisen typen tappion takia ja kylvötuloksen heikennyttyä kylvön jälkeisestä tallauksesta levityksen yhteydessä. Myöhemmin jälkikompostoimattomalla Kemicond-käsitellyllä lietteellä saadut tulokset (julkaisematon aineisto) viittaavat siihen, että kokonaan tai vain vähän aikaa jälkikompostoidun Kemicond-käsitellyllä lietteen orgaaninen typpi jatkaa maassa levitettynä mineralisoitumistaan niin, että analysoitu liukoisen typen määrä antaa aliarvioivan kuvan lietteen todellisesta typpilannoitusvaikutuksesta.

\section{Johtopäätökset}

Tuloksia on vaikea yleistää kaikkiin niiden tyyppinimien lietetuotteisiin, joita tutkitut lietetuotteet periaatteessa edustivat, koska lietetuotteiden ominaisuudet niidenkin sisällä vaihtelevat runsaasti. Runsaasti liukoista typpeä mukanaan tuovien tuotteiden satovaikutukset voivat olla arvaamattomia, ja sadon kannalta oleellista on hyvä kylvötulos. Lietetuotteita, joiden liukoisen typen pitoisuus on hyvin pieni, on mielekkäintä käyttää kevätkyntöisillä mailla keväällä ennen kyntöä. Niillä maalajeilla, joita ei voida kyntää keväällä, tällaiset lietetuotteet voidaan levittää jo syksyllä ja mullata kyntämällä tai kultivoimalla, koska potentiaalisesti huuhtoutuva typen määrä on pieni. Paras vaihtoehto levitysalueeksi olisivat syksyllä perustettavat kasvustot. Levitettäessä kerralla viiden vuoden fosforiannos liukoisen typen määrä jää jopa pieneksi syksyn tarpeen kannalta. Kevätlevityksen ja kasvustoon levityksen kannalta kokeessa mukana olleista ongelmallisin lietetuote on kalkkistabiloitu liete, jonka negatiiviset vaikutukset kylvömuokkauksen yhteydessä mullattuna voivat olla suuret ja voivat olla merkittävät myös kasvustoon levitettynä. Kuivan hienojakoisen kompostoidun ja hyvin vanhennetun vähän liukoista typpeä sisältävän lietteen mahdolliset haitalliset vaikutukset ovat pienet ja pienimmillään kylvömuokkauksella muokattuna. Kokeen kalkkistabiloidulla lietteellä ja kompostoidulla lietteellä ei ollut oleellisia typpilannoitusvaikutuksia, vaan ne ovat luonteelta fosforilannoitteita. Niiden mukana tulee myös muita kivennäisravinteita. Lainsäädäntö (VN 1994, 2000, MMM 2007a) ja ympäristötukijärjestelmä (MMM 2007b) rajaavat niiden käyttömäärän peltokäytössä niin pieneksi, että maanparannusvaikutus jää varsin rajalliseksi. Niinpä niiden käyttö on perustel- 
tua lähinnä, kun pelto kaipaa fosfori- tai muuta kivennäisravinnelannoitusta. Käytetyistä lietetuotteista Kemicond-käsitelty puhdistamoliete poikkeaa muista. Käsittely rikkoo lietteen orgaanisen rakennetta niin, että siihen muodostuu jälkikompostoinnin aikana runsaasti liukoista typpeä tai sitä mineralisoituu levityksen jälkeen maassa. Tämän takia sillä on merkittävä typpilannoitusvaikutus. Jälkikompostoitua Kemicondlietettä voidaan periaatteessa käyttää ainoana ohran kasvinravinteiden lähteenä ainakin joka neljäs vuosi, kun maan fosforiluku on tyydyttävä tai pienempi.

Lietetuotteilla voidaan tuottaa yhtä hyvä ja laadukas sato kuin mineraalilannoitteilla oikein käytettynä. Tutkimuksen lietetuotteista kalkkistabiloitu ja kompostoitu liete soveltuivat kuitenkin lähinnä vain kivennäisravinteiden tarpeen tyydyttämiseen, kun niistä levitysalueella on puutetta. Kalkkistabiloidun lietteen kasveille käyttökelpoisen fosforin pitoisuus oli vain 1,0 - 1,4 kg/t, kompostoidun 3,1 - 3,2 kg/t ja Kemicond-käsitellyn 0,5 - 2,8 kg/t. Kun lannoitefosforin hinta vuoden 2009 lopussa on noin 1,2 €/kg, kalkkistabiloidun lietteen fosforin arvo ei riitä edes levityskustannuksen 2,5€/t kattamiseen eikä kompostoidunkaan lietteen tapauksessa jää merkittävää summaa kuljetuskustannusten kattamiseen. Lietteestä voidaan vuositasolla ottaa noin 15 - $20 \mathrm{~kg} / \mathrm{ha}$ kasveille käyttökelpoista fosforia ylittämättä haitallisten metallien kuormitusrajaa. Kemicond-käsitellyn lietteen arvoa lisää sen sisältään liukoisen typen määrä 3,3-3,4 kg/t lyhyen jälkikompostoinnin jälkeen ja 9,5 kg/t pitkän jälkikompostoinnin jälkeen. Kun lannoitetypen hinta vuoden 2009 lopussa on noin 0,6 €/kg, se lisää ravinnearvoa 2,0 €/t tai 5,7 €/t. Levityskustannusta tarkastellessa on otettava huomioon se, että lietetuotteiden levitys on käytännössä aina erillinen toimenpide kylvöstä toisin kuin lannoitus mineraalilannoitteella. Lyhyenkin aikaa kompostoidun Kemicondkäsitellyn lietteen liukoisen typen pitoisuus on lähellä väkevän sian lietelannan pitoisuutta ja tätä fosforipitoisuus suurempi. Verrattaessa näitä toisiinsa, voidaan todeta, että sian lietelannan kuljetusmatkat jäävät yleensä selvästi lyhyemmäksi kuin lietetuotteiden. Todennäköisimmin viljelijän kannattaa ottaa kalkkistabiloitua lietettä vastaan levitettynä haluttuun aikaan haluttu määrä ilman eri korvausta, jos pellossa on selvää kivennäisravinteiden puutetta, jolloin kuljetus- ja levityskustannus jää lietetuotteen tuottajan kontolle. Kompostoidun lietteen tapauksessa kivennäisravinteiden arvo kattaa levityskustannukset, jolloin viljelijän kannattaa ottaa sitä vastaan, jos maassa on merkittävää tarvetta kivennäisravinteille ja tuottaja vastaa ainakin kuljetuskustannuksesta. Lyhyen aikaakin jälkikompostoidun Kemicond-käsitellyn lietteen liukoisen typen arvo riittää kattamaan levityskustannukset, ja jos maassa on tarvetta lisäksi kivennäisravinteille, viljelijän kannattaa osallistua kuljetuskustannukseenkin jonkin verran. Pitkään jälkikompostoidun Kemicond-käsitellyn lietteen kuljetuskustannuksiin viljelijän kannattaa osallistua jo enemmänkin.

\section{Kirjallisuus}

Eduskunta 2006. Lannoitevalmistelaki 539. Annettu Naantalissa 29. kesäkuuta 2007.

EEC 1986. Council directive of 12 June 1986 on the protection of the environment, and in particular of the soil, when sludge is used in agriculture (86/278/EEC). Official Journal of the European Communities No L181: 1-6.

Kapuinen, P., Perälä, P. \& Regina, K. 2008. Mädätyksen vaikutus sian lietelannan lannoitusominaisuuksiin ohralla. Julkaisussa: Maataloustieteen Päivät 2008. [verkkojulkaisu]. Suomen Maataloustieteellisen Seuran tiedotteita no 23. Toim, Anneli Hopponen. Viitattu 20.11.2009. Julkaistu 9.1.2008. Saatavilla Internetissä: http://smts.fi (Mädätyksen vaikutus sian lietelannan lannoitusominaisuuksiin ohralla). ISBN 978-951-9041-51-3

MMM 2007a. Maa- ja metsätalousministeriön asetus lannoitevalmisteista 12. Annettu Helsingissä 13. helmikuuta 2007.

MMM 2007b. Maa- ja metsätalousminsteriön asetus maatalouden ympäristötuen perus- ja lisätoimenpiteistä ja maatalouden ympäristötuen erityistuista 503. Annettu Helsingissä 26. huhtikuuta 2007.

VN 1994. Valtioneuvoston päätös puhdistamolietteen käytöstä maanviljelyksessä 282. Annettu Helsingissä 14. huhtikuuta 1994.

VN 2000. Valtioneuvoston asetus maataloudesta peräisin olevien nitraattien vesiin pääsyn rajoittamisesta 931. Annettu Helsingissä 9. marraskuuta 2000.

VN 2006. Valtioneuvostonasetus kaatopaikoista annetun valtioneuvoston päätöksen muuttamisesta 202. Annettu Helsingissä 23. maaliskuuta 2006.

VN 2007. Valtioneuvoston asetus täydentävien ehtojen hyvän maatalouden ja ympäristön vaatimusten sekä ympäristöön liittyvien lakisääteisten hoitovaatimusten valvonnasta 636. Annettu Helsingissä 31. toukokuuta 2007. 